\title{
VIETNAM - FRANCE HIGHER EDUCATION SYSTEMS AND UNIVERSITY - UNIVERSITY COOPERATION IN JOINT TRAINING PROGRAMS
}

\author{
Vu Ngoc Tu*, Nguyen Phan Quang \\ VNU International School, 144 Xuan Thuy, Cau Giay, Hanoi, Vietnam
}

Received 10 March 2017

Revised 16 May 2017; Accepted 18 May 2017

\begin{abstract}
France is said to be the nation which brought the modern higher education to Vietnam with the establishment of the University of Indochina in 1906, the first modern university in Vietnam. France is also the country which trained the first professors and managers in the first half of the 20th century. The cooperation between the two countries chiefly that in joint training programs has continuously developed despite all ups and downs in the relation of the two countries. This paper, therefore, looks at these two systems respectively. On the basis of their respective characteristics, challenges and achievements, it points out some similarities and differences between them and some influences that the French higher education (HE) may have on the Vietnamese HE system as well as the role played by joint training programs in Vietnamese - French university- university cooperation.
\end{abstract}

Keywords: current situation, higher education system, cooperation, joint training programs, French University Center (PUF)

\section{Introduction}

The trend of internationalization has become stronger and stronger in the Vietnamese higher education in which more prominent are international joint training programs, the establishment of foreign satellite campuses or foreign universities in Vietnam. Thanks to their supremacy in producing highly qualified human resources, training technology transfer, international joint training programs have quickly developed and attracted the consideration from the government as well as common people. One of Vietnam's big partners of international joint training programs is France. Over the last years, a number of Vietnam - France joint training programs

* Corresponding author. Tel.: 84-913247915

Email: tuvn@isvnu.vn according to the French model have been conducted in Vietnam, but France - Vietnam cooperation in higher education has been of much longer history. Due to history, France is the nation which brought the modern higher education to Vietnam with the establishment of the University of Indochina in 1906, the first modern university in Vietnam. France is also the country which trained the first professors and managers in the first half of the $20^{\text {th }}$ century. The cooperation in higher education between the two countries chiefly the cooperation in joint training programs has continuously developed despite all ups and downs in the relation of the two countries. The question is how to develop more effectively the cooperation in higher education chiefly in international joint training programs for the benefit of the two nations. This paper, therefore, presents: (i). the current situations of the French and 
Vietnamese higher education respectively, (ii). French education in Vietnam, (iii). university - university cooperation in joint training programs and then points out some suggestions and recommendations for further cooperation.

\section{French higher education system}

\subsection{Current situation}

French higher education system awards the following degrees recognized by the Bologna Process: Bachelor's degree (3 years), Master's (2 years), and doctorate (3 years). French universities have also adopted the ECTS credit system (for example, a Bachelor's degree is composed of 180 credits). However, the traditional curriculum based on the end of semester examinations still remains in place in most universities. This double standard has added complexity to a system which also remains quite rigid. It is difficult to change a major during undergraduate studies without losing a semester or even a whole year. Students usually have few course selection options once they enroll in a particular diploma. In other words, France has a complicated system of higher education. However, it might be right to say that the French HE system consists of two main types of institutions: (i). universities and (ii). Grandes Ecoles.

(i). Universities: France has 82 state universities, five Catholic universities and a number of private institutes, which are under the theoretical control of the local education authority, and are run by a board presided over by an elected president. The presidents of universities are elected by the board for a period of 4 years and can hold the position for two terms. The board consists of elected representatives of the teaching staff (about $50 \%$ of members), of administrative staff and students, plus external members representing local interests .

It should be noted that French universities are in the process of reorganizing themselves into massive local federations of existing universities and institutes of higher education, known as higher education and research centers with an aim to save money, by merging some of the administrative structures currently duplicated in each university or institution and to make French universities more "visible" on the international stage so as boost the ranking of French universities in international higher education community.

- Catholic universities offer the same range of degree courses as state universities, and students can freely move between the two systems.

- Private universities and other private institutions: It seems that there are no private universities except the Catholic ones. There are other private institutions - schools which include some of the grandes écoles and a great number of private establishments offering business degrees, technical qualifications and other courses. To offer a degree, a school must have its courses recognized by the Ministry, in the same way as public universities .

French universities are ranked among the most efficient institutions of higher education in any developed countries in terms of the ratio between investment per student, quality and the results obtained although they are considerably underfunded.

(ii). Grandes Ecoles are higher education institutions which focus on a single subject area, such as engineering or business, have a moderate size, and are often quite selective in their admission of students. They provide a cosseted higher education to the nation's future elites, leaders of industry, top military brass, top politicians, engineers, physicists and others. Grandes Ecoles are very well funded, have small classes and top teaching staff and some of them are very famous all over the world 
2.2. French higher education's superior characteristics

Nguyen Trong Do (2011) is right to say that the French higher education has three main superior characteristics as follows:

(i). Democratic: The history of the French education is said to be the history of democratizing higher education. Thanks to the reforms in the two decades 1980 - 1990, French universities have become even more democratic through the students' participation and role in the process of university management.

(ii). Enlightening: Being greatly influenced by churches, French universities have gradually become institutions of enlightening, playing an extremely important role in the social progress. The respect for truth, teacher - students relation, academic freedom, relative independence from the state have become great traditions of the French higher education. They are the very important conditions for formulating up a contingent of intellectuals that France can be proud of.

(iii). Public good: Up till now, most French universities are public universities. It is based on the value or belief that considers education as activities of public good, different from market values. It is well known that after the students' movement in May, 1968 all French universities are open to all "bacheliers" - those who have passed their "baccalaureats" (except scientific and medical training programs). Since higher education is funded by the state, the fees are low; the tuition ranges from 150 Euros/year to 700 Euros/year depending on the university and the different levels of education: Bachelor, Master, and Doctorate respectively .

It is commonly stated that low expenses have ensured the equity of education for everyone, and thus making French universities more attractive for foreign students. That is exemplified by the number of foreign students in French universities: over 263,000 in 2006 occupying 11.7\%, ranking as $4^{\text {th }}$ country after America and Australia in attracting foreign students.

\subsection{French higher education's achievements}

Being an old system, the French higher education is one of the HE systems that has recorded greatest achievements in the world. These achievements can be illustrated by its quantity (the number of universities, students, teaching staff, training scope and modern infrastructure...) and quality (excellent professors/scientists/ Nobel Laureates, achievements in science, technology, engineering, culture and art...). In the age of globalization, French universities' achievements have had a profound international influence (Nguyen Van Do, 1996).

(i). In terms of quantity, it can be said that France is one of the countries that has the biggest and most developed higher education. At present, French universities and higher institutions accept hundred thousands of students a year not only from France but also from hundreds of foreign countries. These figures have unceasingly increased over the years. For example, in 1950 the number of students was only 136,744 compared to $2,338,100$ in 2017 , and also in 1950 , the teaching staff was just 5,799 in comparison with 91,000 in 2017. That is of special significance because France is a country that has the oldest population in Europe (Nguyen Van Do, 1996).

(i). In terms of quality, the French higher education has produced hundreds of leading scientists in the fields of sciences, art, politics, economics, among whom dozens are great men of the humankind. In the $20^{\text {th }}$ century, this higher education produced 57 Nobel Laureates, not to mention those French of other origins or those who were 
trained in France and a number of Fields winners . Prof. Ngo Bao Chau bearing both Vietnamese and French nationalities who received the Fields award was also trained and then worked in France.

In the field of social sciences, one cannot help but mention a series of theories, doctrines and trends of thoughts originating from France with excellent representatives like Rousseau, Jean-Paul Sartres, Derrida, but first and foremost, one should mention Descartes with his rationalism - the origin of Western education.

The high quality of the French higher education is also partially reflected in the university ranking table in 2017 including: Ecole Normale Superieur, Paris (66), Ecole Polytechnique (116), University Pierre et Marie Curie (121), University of Paris Sud (179) and Ecole Normal Superieure de Lyon (201)....

\subsection{Challenges for French higher education}

Nguyen Trong Do, et.al (ibid) holds that the French higher education is facing big challenges relating to educational methodology, finance and management, and international competition.

(i). Educational methodology:

Relating to the French educational philosophy of enlightenment, students are trained to discover the general, fundamental knowledge. This methodology focuses on communication rather than criticism, considering theory more important than practice. In this modern world, the American methodology focusing on practice seems to be more appropriate as it produces human resources that can easily meet the requirements of the labor markets.

(ii). Finance and management:

The literature shows that French universities are not highly competitive as other universities in other countries. Due to very low tuitions, French universities are always struggling with the financial shortage thus leading to backward physical facilities. The French education is now facing the dilemma problem: pressure from the market mechanism, first and foremost, whether to impose higher tuition fees so as to upgrade physical facilities and improve quality or to maintain the existing mechanism to ensure the equity of education.

The French HE management has not been considerably changed since 1968. Mrs.Valerie Pecresse, French Minister of Higher Education also emphasized the autonomy of each university. The management staff of each university should reduce from 60 to 20-30 people. The university presidents should be entitled to spend money in their way including high pays so as to attract or to keep excellent professors.

(iii). Internationalization:

In order to integrate into the European and world HE community, France has to reform its universities. Together with applying Bologna Process (L-M-D), French universities have to change their programs in such a way that their credits can be easily transferred and accepted in other countries in the world.

It goes without saying that over the last decades, globalization has become the main trend of the humankind and the English language has become more predominant. In reality, English has become lingua franca of the Internet age and it is even truer in the field of higher education. Today, most scientific conferences/workshops are conducted in English; scientific works are also published in English. In addition, in countries like Korea, the percentage of training programs conducted in English is considered as an important factor for receiving financial support from the government. The predominance of English also means the decrease of the role of the 
French language. Nowadays, even some training programs of French universities are conducted in English. Accepting this reality means that the French higher education has to accept the competition with a lot of disadvantages: French professors have to be good at English so that they can teach international programs and have their research results published in English journals.

What is more, complying with the Bologna Process, accepting the ECTS system and at the same time keeping the traditional curriculum based on end of semester examinations have made the French higher education even more complicated and to some extent, even more difficult for its internationalization.

In short, the French higher education is of an age-old tradition and famous for its quality. That is a higher education of enlightening, full of humanistic characteristics. It has produced a lot of great men and thus has played an important role in the world higher education community. Although it may have some challenges to overcome, they are not as serious as those the Vietnamese higher education has to face.

\section{Vietnamese higher education system}

\subsection{Current situation}

The Vietnamese HE system certainly has some differences with the French HE system in terms of its history of development, its high quality and diversity as well as its attractiveness to foreign students. Unlike the French higher education, the modern Vietnamese higher education came into being much later than the French higher education and it was the result of the West - East cultural exchange, chiefly under the French domination. The modern
Vietnamese higher education first appeared with the establishment of the University of Indochina by the French in 1906. Since then, the Vietnamese HE system has seen a lot of changes for further development. At present, the number of HE institutions has increased and the training quality has gradually improved. From a system consisting of only narrowly specialized universities with only Bachelor and Ph.D degrees following the former Soviet model, now it has a number of multi-disciplinary/ comprehensive universities offering Associate, Bachelor, Master and $\mathrm{PhD}$ programs.

The Vietnamese HE system consists of the following 7 types of universities not to mention colleges and continuing education schools/institutions:

(i). Specialized universities each of which focuses on a certain single area of study, such as economics, banking, law, technology, agriculture, forestry, fishery ...;

(ii). Multi-disciplinary (comprehensive) universities including three newly established regional universities in some of Vietnam's largest cities;

(iii). National universities, one in Hanoi established in 1993 and one in Ho Chi Minh City established in 1995;

(iv). Regional universities: Hue, Da Nang and Thai Nguyen;

(v). Open universities: two open universities established in 1994, one in Hanoi and one in Ho Chi Minh City;

(vi). Foreign universities and;

(vii). Vietnamese - foreign universities.

At present, there are 644 higher education institutions out of which about 100 are nonpublic in comparison with 376 in 2009 .

Vietnamese higher education is organized into public and non-public (people-founded/ private). Public institutions receive funding for infrastructure, facilities and operational expenditures. Private institutions are funded 
by social, professional, and economic organizations or individuals for infrastructure, facilities and operational expenditures. The government supports public institutions to ensure that they always play the key role in the national education system. In addition, there are institutions with foreign invested capital: (i). $100 \%$ foreign invested institutions and (ii) joint venture institutions (Higher Education Law, 2012).

Colleges normally offer three-year programs and award Associate diplomas to those who graduate. About two-thirds of Vietnam's colleges specialize in training teachers for lower levels of the education system. Colleges are small and the students in these colleges make up a small part of the total enrolled in public higher education.

In terms of management, it is worth noting that universities and colleges are not only managed by the Ministry of Education and Training (MOET) but also by various ministries and provincial people's committees: by MOET (over 100/644, by other ministries such as the Ministry of Public Security (11 universities/academies/colleges), the Ministry of Defence (25) and by provincial people's committees. At present, 40/63 provinces and cities have universities accounting for $65 \%, 60 / 63$ provinces have colleges making up 95\%. Most of Vietnam's college-level institutions are managed by provincial people's committees (Nguyen Van Nha \& Vu Ngoc Tu, 2015).

Unlike the French HE system, the Vietnamese HE system does not have "grandes écoles". Vietnamese universities are also run by a board presided by a president, but the board consists of representatives of all academic departments and some representatives of some functional departments; no representative of students. The presidents are appointed by the minister of the Ministry of Education and
Training except that the presidents and vice presidents of the two national universities who are appointed by the Prime Minister.

\subsection{Vietnamese higher education's achievements}

Vietnamese higher education over the last decades has achieved encouraging results. According to MOET, over 20 years of reform, it has remarkably developed its scope, diversified university types and training modes; begun to adjust the structure of the system, improved training programs and training process; mobilized more resources from the society. The quality of some training areas has been gradually enhanced. The HE system has produced qualified human resources to meet the requirements of the socioeconomic development and industrialization and modernization of the country, to ensure national security and defence and speed up the process of international integration. University and college management has also been improved. More importantly, it has narrowed the gap between Vietnamese higher education and world HE community and has confirmed its further development.

The establishment of the two national universities, three regional universities, some Vietnamese - foreign universities and several $100 \%$ foreign-owned universities is also considered as an encouraging result of the higher education reform. The idea behind all this is to build a higher education that is multi-tiered and that includes higher education institutions operating under different ownership models (public, private and mixed). These universities are said to be Vietnam's first research-oriented universities which are more autonomous than other Vietnamese universities and they are the first universities to hire administrators and $50-80 \%$ foreign lecturers. However, as higher education is one of the three 
key areas (renovation in mechanism and policy and renovation in administration and building a strong and transparent State machinery) in which to create a breakthrough to change the socio-economic situation and vigorously develop human resources, the Vietnamese HE reform must continue to be carried forward (Vu Ngoc Tu, 2012).

\subsection{Challenges facing Vietnamese higher education reform}

Although the Vietnamese higher education has recorded encouraging results over the last decades, it has to be still continued to be reformed as "without urgent and fundamental reform to higher education system, Vietnam will fail to achieve its enormous potential" and there is a "close relationship between development and higher education" (Vallely, 2008).

There are more challenges that face the Vietnamese higher education compared to those that face the French higher education. Hayden (2005), MOET's World Bank consultant, groups these challenges into four categories: finance, management (governance), quality and equity of access. However, there are other challenges that should be mentioned. Vu Ngoc Tu (2004), and Nguyen Van Nha \& Vu Ngoc Tu (2015) point out 10 main challenges as follows:

(i). The biggest challenge is to ensure that the system of education and training responds to the emerging demands of a growing economy, that is, to satisfy the requirements for human resources of the country's industrialization and modernization and people's learning requirements. Moreover, the training scope has not yet met the requirements of industrialization and modernization; there is imbalance between supply and demand;

(ii). Inappropriate structure of the higher education system is manifested by separating the network of higher education institutions from research academies thus reducing investment efficiency and the quality of training and research. Moreover, research is not paid due attention to, teaching is not yet closely linked with research and services for social life;

(iii). Financial resources are limited, mainly relying on the State budget. In addition, the centrally determined structure of funding proves to be inefficient and counterproductive. Most of the HE institutions in Vietnam are inactive in finding other financial resources. Hayden (2005) states that the level of funding for Vietnam's higher education is small: only $0.41 \%$ of GDP in 2002 out of a total of $4.22 \%$ for all levels of education. In terms of expenditure on higher education, Vietnam compares poorly to the rest of the region and the rest of the world (average is $1.22 \%$ );

(iv). Training quality, content and methods should be improved as training quality and efficiency are still low. That is confirmed by Vallely (2008) who states that Vietnam does not have even a single university of recognized quality. Learning is not closely combined with practice, and therefore, human resources produced are not highly qualified. Training programs are inflexible focusing on theory rather than practice and slow in integration; learning and teaching methods are outdated, the training process is closed and inflexible. In general, HE institutions have limited research capacity; faculty qualifications are generally low and vary significantly across types of institutions and regions. Although Vietnam's HE system has recently introduced internal quality measures, it still lacks external quality measures. Teaching methods are backward, the level of articulation and global integration is low. The progress of renovation is slow because of the slow-changing mindset of teachers and their heavy teaching load (World Bank, 2007); 
(v). Teaching and administrative staff have not yet been able to meet the requirements of HE reform both in terms of quality and quantity. At present, there are only 77,000 HE teachers/ lecturers out of which only 9,126 have Ph.D. degrees and 36,347 have Master degrees; and 300,000 management personnel for the whole education system from general education to higher education (MOET, August 2012). There is a serious lack of research experts, and HE policy makers. Moreover, many lecturers do not pay due attention to research;

(vi). Management is characterized by a very high level of centralization. MOET has significant power over higher education and determines matters as varied as student enrolment, academic assessment, budget decisions, and infrastructure and facility maintenance. There is a severe lack of close links between higher education institutions and scientific research, businesses, industries and employers. The existing mechanism and policies have not yet created selfaccountability, responsibility of HE institutions for personnel, revenue-expenditure balance, and quality of training products;

(vii). Competition is not created for $\mathrm{HE}$ development. HE institutions' development plans are not clear, just short-term rather than long-.term and HE institutions are not rationally distributed over the whole country thus reducing investment efficiency;

(viii). Higher education reform has not been able to keep pace with economic reform and requirements for integration; HE management cannot keep pace with HE socialization;

(ix). Vietnam higher education has always affirmed the equity of access very much in line with "admission to higher education should be based on the merit, capacity, efforts, perseverance and devotion and can take place in a lifelong scheme, at any time, with due recognition of previous acquired skills" (UNESCO, 1998). However, at present, certain groups (women, ethnic minorities, the less privileged, those from particular regional areas) are not represented in higher education proportionately to their numbers in the population. The reason for this is that poverty in Vietnam has a geographical aspect, the poorer regions tend to have fewer $\mathrm{HE}$ institutions, and people just cannot pay for their higher education and this consequently results in a lower level of enrolment.

(x). Curricula "as the bulk of Vietnamese curricula do not meet the needs of about $60 \%$ young laborers who graduate from training establishments need to be retrained for at least 6-12 months after being recruited" (Nuffic Neso/Vietnam).

(xi). International competition: Vietnam's open door policy has made the Vietnamese higher education an integral part of the world HE community thus leading to the competition between Vietnamese and foreign universities not to mention foreign universities in Vietnam. According to recent statistics of Vietnam Ministry of Education and Training, the number of Vietnamese students studying overseas has been increasing to over 60,000 .

Although there are many challenges that face the Vietnamese higher education reform, they have to be surpassed. Only by successfully overcoming those challenges, can the Vietnamese higher education achieve its main objective: to produce highly qualified human resources for Vietnam's socioeconomic development.

As has been pointed out in the previous sections, there are some differences and similarities between the Vietnamese and French HE systems which can be summarized in Table 1. 
Table 1. Similarities and differences between Vietnamese and French higher education systems

\begin{tabular}{|c|c|c|}
\hline Comparison & Vietnamese HE & French HE \\
\hline \multicolumn{3}{|l|}{ Similarities } \\
\hline Budget & Mainly relying on State budget & Mainly relying on State budget \\
\hline Competition & Low & Low \\
\hline Management & High level of concentration & High level of concentration \\
\hline $\begin{array}{l}\text { Educational } \\
\text { methodology }\end{array}$ & Theory more important than practice & Theory more important than practice \\
\hline \multicolumn{3}{|l|}{ Differences } \\
\hline \multirow{2}{*}{ System } & Still being planned & Planned and developed \\
\hline & Without churches' influences & Mostly influenced by churches \\
\hline Structure & Inappropriate & Appropriate \\
\hline Universities & Many narrowly specialized & $\begin{array}{l}\text { All comprehensive except Grandes } \\
\text { Ecole }\end{array}$ \\
\hline Staff & $\begin{array}{l}\text { Teaching and administrative staff: poor } \\
\text { quality }\end{array}$ & $\begin{array}{l}\text { Teaching and administrative staff: high } \\
\text { quality }\end{array}$ \\
\hline $\begin{array}{c}\text { Training and research } \\
\text { quality }\end{array}$ & Poor & High (many Nobel Laureates) \\
\hline $\begin{array}{c}\text { Curricula/training } \\
\text { contents }\end{array}$ & Inappropriate & Appropriate and modern \\
\hline $\begin{array}{c}\text { Teaching/learning } \\
\text { method }\end{array}$ & Backward & Modern \\
\hline Equity of access & Guaranteed & Not guaranteed \\
\hline Entrance to university & Highly competitive & Open to all \\
\hline Tradition/history & Short & Age-old \\
\hline $\begin{array}{l}\text { Attractiveness to } \\
\text { foreign students }\end{array}$ & Little & Much \\
\hline
\end{tabular}

\section{French higher education in Vietnam}

\subsection{French - Vietnamese higher education}

After occupying Vietnam, the French faced with the greatest difficulty in the language barrier. To overcome this difficulty, the French set up an institution to train interpreters and that was considered as the first French vocational school/institution in Vietnam. Along with training interpreters, the French government opened some more training areas in administration, justice and finance.

The French - Vietnamese higher education (Enseignement Franco- Indigene) was introduced to Vietnam with some modifications and adjustments of the French training mechanism and organization to suit the Indochinese conditions. It consisted of two types of institutions: (i). Ecole Superieure - vocational schools/institutions and (ii). universities.

In early 20th century, the French Vietnamese higher education became more stable with the French government's permission to open more vocational institutions like Medicine - Pharmacy, Pedagogy, Law... All these schools/institutions were in Hanoi and belonged to the University of Indochina. The University of Indochina at that time consisted of School of Indochinese Medicine, School of Public Administration, School of Indochinese Veterinary, School of Law and Administration, School of Pedagogy, School of Agriculture and 
Forestry, School of Indochinese Commerce, School of Letters (it then merged with the School of Law and Administration), School of Applied Science, School of Indochinese Art. The training programs lasted for 3 years but from 1926 they changed to 5 years. After that, more programs were formulated: Architecture, Lacquer Painting and Ciselure (Nguyen Van Do, 1996).

In short, we can say that the French higher education system still has had some influences on the Vietnamese HE system. However, there are a number of differences between the two higher education systems. One striking difference student recruitment - should be re-emphasized. While French universities are open to all high school students - those who have passed their "baccalaureat", except the scientific and medical programs, the entrance to Vietnamese universities can be highly competitive (Table 1).

\subsection{French higher education in Vietnam at present}

As was mentioned earlier, in the context that higher education has become a market, France has made more and more concrete plans to reform its high education to make it suitable to the world as well as Vietnamese development. Along with scholarships awarded to Vietnamese staff and students for further study in France, the French government has paid more and more attention to conducting French training programs in Vietnam in which the most predominant may be:

(i). French language programs with an aim to support Vietnamese training programs by offering subjects in French. In Vietnam, with the support from AUF, the number of subjects conducted in French or by French or Vietnamese lecturers has considerably increased. Out of 15,000 Vietnamese learners of French, $22 \%$ are students in programs conducted in French like Construction and Urban Planning, Biotechnology, Food Processing, Economics and Management, Geography and Tourism, Medicine, Informatics, New Technology, Chemistry and Environment (Nguyen Trong Do, et.al, 2011).. (ii). Joint training programs in Vietnam according to the French standards with degrees awarded by French universities: The typical program of this type is the Excellent Engineer Training Program (PFIEV) that has been offered in Vietnam over the last 10 years. This is a complete engineering training program according French model and standards and at the same time suitable to the Vietnamese conditions with the academic support from 8 leading universities in the field of training engineers: INSA Lyon, INPG, ENPC, ECP, ENSMA, ENSEEIHT $<$ ENST, Lycee LOUISDE GRAND). This program has been highly appreciated by both the Vietnamese Ministry of Education and the French Embassy in Vietnam.

(iii). $100 \%$ French programs with degrees awarded by French universities have been conducted since 1992. The first MBA of this type was offered in French and English by the French-Vietnamese Center for Management Education (CFVG) and Hanoi National Economics University, Vietnam. The CFVG degree is also signed by the Vietnamese Ministry of Education and Training as well as the Vietnamese Department of Industry and Commerce and internationally recognized.

According to Nguyen Trong Do, et.al (ibid), there are 22 training institutions which offer 57 joint programs with French universities: 16 undergraduate, 39 Master and $2 \mathrm{PhD}$. The most attractive training areas seem to be Economics with 16 Master programs and 12 undergraduate programs followed by Science - Technology with 1 undergraduate, 12 Master and $1 \mathrm{PhD}$ programs, the medicine with 3 Master and 1 graduate program... Programs in economics are most selected because they meet the requirements for development of Vietnam and at the same time they do not require a lot of investment in physical facilities, equipment or laboratories.

\subsection{French University Center (PUF) in Vietnam National University, Hanoi (VNU)}

With Vietnam's open door policy and reforms, and withits position gradually confirmed 
in the region and with Vietnam entering WTO, Vietnam and France want to intensify their cooperation in training and research. Besides offering joint programs in Vietnam, the two governments' scholarship policy over the last 10 years has enabled 3,500 Vietnamese students to study in France. Experiences in France Vietnam cooperation in higher education have shown that joint programs should be grouped into one place so as to utilize all existing resources. In that connection, the signing of the agreement on setting up two French university centers (Poles Universitaires Francais) was of great significance. The main aim of these centers is to turn the bilateral cooperation between France and Vietnam in higher education to a new model thus contributing to further development of the Vietnamese higher education; to be more concretely, to set up and develop training programs of international standards in Vietnam and gradually transfer French training technology to Vietnam.

It can be said that since its establishment PUF has gradually achieved its aim and objectives set at the beginning and attained encouraging achievements. Some of the main achievements are as follows.

\section{(a). Management}

In terms of the management, it is right to say that the French university management according to the French university model has been gradually transferred to Vietnamese participating universities.

(b). Training

So far, PUF has conducted 7 joint training programs on the basis of the L-M-D model (3 years for Bachelor, 2 years for Master and 3 years for Doctorate) very much in line with Bologna Process. All these programs have been conducted smoothly and effectively: the input quality has unceasingly improved; their prestige has been admitted by the society. Student recruitment, teaching and learning methods, testing and training management, graduation approval have been carried out according to the regulations of the French universities and in accordance with the real situations of the Vietnamese education.

\section{(c). Research}

As far as research is concerned, priority has been given to research on areas relating to training programs, conducting new $\mathrm{PhD}$ programs, organizing conferences/workshops and other activities.

So far, PUF has organized different scientific workshops on: (i) the method of organizing graduate training programs, setting up research groups in the School of Law, (ii) high-level research projects in the University of Social Sciences and Humanity... However, one has to confess that scientific research activities have not been up to the expectation.

(d). Improving teaching staff

The Vietnamese lecturers have received lecture notes, materials and training technology from their French colleagues by various means: study tour, workshops, class observation, teaching assistance, coaching, seminars...) so as to conduct PUF's joint training programs and at the same time apply them to other training programs in their universities.

(e). Collaborating with enterprises

With its prestige in conducting high quality training programs, PUF has invited experts from enterprises and research institutes to participate in teaching and accept students for internships, for example: France Orange Telecom, Accor, Sunway Hotel, IRD, Big C just to name a few.

It might be right to say that since its establishment PUF has proved not only its effective operation but also its sustainability for training technology transfer. PUF has become an important factor in the French higher education in Vietnam, thus contributing to raising the status of the French higher education in Vietnam through its high quality joint training programs and research projects.

\section{Suggestions and recommendations}

From what has been presented above, the Vietnam - France cooperation in higher education has recorded encouraging achievements benefiting both systems and countries. In that connection, Vietnamese 
higher education should continue to strengthen cooperation with its French counterpart. The common forms of cooperation which have proved effective can be: (i). joint training programs and joint research projects, (ii). co-organisation of scientific conferences/ workshops, (iv). student and staff exchanges, and (v). exchange of information and materials... The Vietnamese higher education should focus its cooperation on the areas that France is strong at and that meet the requirements for qualified human resources training and development. These areas could be: Economics and Management, Science - Technology, Medicine and Pharmacy, Construction and Urban Planning, Biotechnology, Food Processing, Geography and Tourism, Informatics, New Technology, Chemistry and Environment, Excellent Engineer Training Program (PFIEV). Relating to joint training levels, it should promote all the joint Bachelor's, Master, and Doctoral programs with the language of instruction being English. What is more, with the two governments' support, the PUF model should be multiplied and applied in other universities.

\section{Conclusion}

Internationalization and globalization might be one of the solutions for the Vietnamese higher education to create a breakthrough in improving its training and research quality thus keeping up with the regional and world higher education community. In other words, for the Vietnamese higher education to realize its most important mission: to produce highly qualified human resources for Vietnam's socio-economic development, Vietnamese universities have to speed up their cooperation and links with foreign universities in the world in general and in France in particular. It has been proved that the most known common forms of cooperation between Vietnamese and French universities such as collaborative research on areas of common interest, co-organization of international workshops/conferences, staff and student exchange, exchange of information and materials and scholarship programs, the cooperation in joint training programs have been effectively carried out.

It has been proved that the Vietnamese higher education, to some extent, has been influenced by the French higher education; therefore, it crystallizes the fine characteristics of the ancient Vietnamese education and the modern Western education. The Vietnam France cooperation in higher education can be said to start from the establishment of the University of Indochina in 1906. This cooperation has continuously developed despite all ups and downs in the relation between the two countries thus contributing to Vietnam's highly qualified human resources development as well as Vietnam's socioeconomic development and therefore, it should be continued to be consolidated and further developed.

\section{References}

Hayden, M. (2005) The legislative and regulatory environment of higher education in Vietnam. Washington, DC: The World Bank, 2005.

Hayden, M \& Lam QuangThiep (2007). A 2020 vision for Vietnam, International Higher Education, No. 44, pp. 11-13.

Higher Education Law, 16 June, 2012.

Le Van Giang et.al. (1985). History of Vietnam's higher education and vocational training, Hanoi.

MOET. Vietnam Higher Education Renovation Agenda period 2011-2020.

MOET. Higher Education Consolidation and Reform Project in the period 2006-2020.

Nguyen Van Do (1996). Higher education - A Pivotal lever for socio-economic development in developing countries in the $21 \mathrm{st}$ Century. International Conference, Hanoi.

Nguyen Trong Do et.al (2011). Building up a theoretical, practical model and solutions to improve the efficiency, quality and sustainability of the French universities' training programs in Vietnam national University, Hanoi.

Que Anh Dang (2009). Recent higher education reforms in Vietnam: The role of World Bank. 
Vallely T. \& Wilkinson B (2008). Vietnam higher education: Crisis and respond. Harvard Kennedy School.

Vu Ngoc Tu (2012). Vietnam Higher Education Reform: Challenges and solutions, in International Conference Proceedings on Inclusive Innovation and Innovative Management in Bangkok, Thailand.

Nguyen Van Nha, Vu Ngoc Tu (2015). Higher Education Reform: Current Situations, Challenges and Solutions, VNU Journal of Science. Vol. 31, No.4, 2015

UNESCO (1998). World declaration on higher education for the twenty-first century: Vision and action.

World Bank, Vietnam (2007). Higher education and skills for growth, Human Development Department, East Asia and Pacific Region, 4 May, 2007.

\section{Online sources}

Nuffic Neso Vietnam

$<$ http://www.google.com.vn/search?q=nuffic + neso+tre nd + in + vietnamese+higher+education + reform \&ie $=$ utf. 8 \&oe=utf-8\&aq=t\&rl>. Accessed 10/2/201715:25

French universities - Higher education in France. About-France. $\quad$ Com $<$ https://www.google.com/ search?q=http://about-france.com/higher-educationsystem $\&$ ie $=$ utf- $8 \&$ oe $=u t f-8 \&$ client $=$ firefox $-b \& g f e$ $\mathrm{rd}=\mathrm{cr} \& \mathrm{ei}=\mathrm{B} 9 \mathrm{ASW}$ dHhKozM8geluLyYBw $>$. Accessed 11/2/20179:25
Tertiary Education Statistics - Statistics Explained and French universities - Higher Education in France. About-France.com

$<$ https:/www.google.com/search?q=number+of + stude nts + in + france $\&$ ie $=$ utf- $8 \&$ oe $=$ utf- $8 \&$ client $=$ firefoxb\&gfe_rd=cr\&ei $=$ V6sSWcGuNpG18wfWk4GY Dw $>$. Accessed 7/02/17 1:30

Teaching staff in public higher education under the responsibility of the French Ministry of Education, Higher Education and research $<$ https://www. google.com/search?sclient=psy-ab\&client=firefox$\mathrm{b} \& \mathrm{q}=$ number + of + teaching + staff $+\mathrm{in}+$ france $\&$ oq $=\mathrm{n}$ umber+of+teaching + staff + in + france $\&$ gs_l $1=$ serp. 3 $=1 \&$ gfe_rd $=$ cr $>$. Accessed 7/02/17 10:30

Danh sách các trường đại học, học viện và cao đẳng tại Việt Nam <http://wikipedia.org/danh/sach/cac/ truong/dai hoc/hoc vienvacao dang taivietnam $>$. Accessed 02/03/2017 9:45

60.000 sinh viên: Nguồn nhân lực tương lai - Tư vấn du học <https://www.google.com/search?q=so+lu ong $+\sinh +$ vien + o + nuoc + ngoai\&ie $=$ utf $-8 \&$ oe $=$ utf $8 \&$ client $=$ firefox-b\&gfe $r d=c r \& e i=y Z s S W a L c K P H$ N8gfPopLYBQ $>$. Accessed 17/02/17 15:30

27 Top Universities in France 2017/ THE Rankings $<$ http://www.mastersportal.eu/ranking-country/10/ france.html >. Accessed11/01/17 14:30

\title{
HỆ THỐNG GIÁO DỤC ĐẠI HỌC VIẸT - PHÁP VÀ HợP TÁC ĐÀO TẠO LIÊN KẾT GIŨ̃A CÁC ĐẠI HỌC
}

\author{
Vũ Ngọc Tú, Nguyễn Phan Quang \\ Khoa Quốc tế học, ĐHQGHN, 144 Xuân Thủy, Cầu Giấy, Hà Nội, Việt Nam
}

Tóm tắt: Pháp được coi là quốc gia đưa giáo dục đại học hiện đại đến Việt Nam với sự thành lập Đại học Đông Dương năm 1906, trường đại học hiện đại đầu tiên ở Việt Nam. Pháp cũng là đất nước đã đào tạo ra thế hệ giáo sư và nhà quản lý đầu tiên vào nửa đầu thế kỷ XX. Hợp tác giữa hai nước cơ bản thông qua các chương trình đào tạo liên kết và đã liên tục phát triển bất chấp những thăng trầm trong quan hệ giữa hai nước. Vì lẽ đó, bài viết này xem xét từng hệ thống trong hai hệ thống giáo dục đại học này. Trên cơ sở những đặc điểm, thách thức và thành tựu riêng của chúng, bài viết chỉ ra những điểm tương đồng và khác biệt giữa hai hệ thống và những ảnh hưởng của giáo dục đại học Pháp đối với giáo dục đại học Việt Nam cũng như vai trò của các chương trình đào tạo liên kết trong hợp tác giữa các đại học ở Việt Nam và Pháp.

Từ khoá: hiện trạng, hệ thống giáo dục đại học, hợp tác, chương trình đào tạo liên kết, Trung tâm Đại học Pháp (PUF) 